\title{
A New Temporality of Religion
}

\section{On Political Theology and Its Ethical Core}

\author{
Lenart Škof \\ Prof Dr; Science and Research Centre Koper, Institute for Philosophical \\ Studies, Koper, Slovenia \\ lenart.skof@guest.arnes.si
}

\begin{abstract}
In his insightful essay »Prophetic Religion and the Future of Capitalist Civilization« Cornel West fervently addressed a question of our abilities to imagine a more empathetic, more compassionate, and also more hospitable world, in which we could foresee, or perhaps already lay ground for a future community where the word religion would simply mean that we live our lives in the consciousness of our finitude and thus in an existential and cognitive humility. This kind of religion (not far from Dewey's or Rorty's ideals) would enable us to see beyond the margins of any narrow-minded religious ideology or any violent incarnation of religion.

Based on these initial thoughts, we first wish to discuss two basic concepts of contemporary political theology - community and vulnerability. We shall argue that we need to offer in contemporary political theology a basic ethico-democratic response, infused with our imaginative capacity for remembrance (Benjamin, Metz) and future hope (West, Dewey, Unger). We will argue with Unger (The Religion of the Future) that we need to live through accepting an enhanced vulnerability, being shared in our democratic (and) religious communities. From this view any loss of human life and its potentials is a sign of a grave injustice, and a catastrophe from an ethical point of view.

Finally, we will propose the so called reverse thesis on religion - namely that today, perhaps, we should first look at religion in its radicalized ethico-political form which only later enables us to think about its various variations and incarnations within different traditions and cultures. We will argue that it is within this newly acquired temporality of religion and its inherent ontologico-political paradox, that it is possible to imagine a future place where recurrent hope for $a$ life is reborn and nurtured within future pluralistic / inclusivistic / democratic / post-Christian communities, based on compassion and shared vulnerability, and not any more on power, or any other form of violence.
\end{abstract}




\section{Keywords}

political theology - John Dewey - Richard Rorty - Cornel West - R.M. Unger vulnerability - community - remembrance

\section{Introduction}

In his insightful essay »Prophetic Religion and the Future of Capitalist Civilization« Cornel West fervently addressed a question of our abilities to imagine a more empathetic, more compassionate, and also more hospitable world, in which we could foresee, or perhaps already lay ground for a future community where the word religion would simply mean that we live our lives in the consciousness of our finitude and thus in an existential and cognitive humility. This kind of religion (not far from Dewey's or Rorty's ideals) would enable us to see beyond the margins of any narrow-minded religious ideology or any violent incarnation of religion. I shall argue on this article that we need to offer in contemporary political theology a strong ethico-democratic response, infused with our imaginative capacity for remembrance and future hope. I will argue here that we need to live through accepting an enhanced vulnerability, being shared in our democratic (and) religious communities. From this view any loss of human life and its potentials is a sign of a grave injustice, and a catastrophe from an ethical point of view. Finally, at the end of this article I will try to propose that today, perhaps, we should first look at religion in its radicalized ethico-political form which only later enables us to think about its various variations and incarnations within different traditions and cultures. I will argue that it is within this newly acquired double temporality of religion and its inherent ontologico-political paradox, that it is possible to imagine a future place where recurrent hope for $a$ life is reborn and nurtured within future pluralistic / inclusivistic / democratic / post-Christian communities, based on compassion and shared vulnerability, and not any more on power, or any other form of violence.

\section{First Temporality of Religion: from West to Benjamin}

Let me start with Cornel West. In his talk at a public event in New York held October 2009, ${ }^{1}$ Cornel West addressed in his typical style, with a strong personal

1 See The Power of Religion in the Public Sphere, ed. by E. Mendieta and J. Vanantwerpen (New York: Columbia University Press, 2011), 92-100. 
and prophetic note, a question of our abilities to imagine a more empathetic, more compassionate, and also more hospitable world, in which we could foresee, or perhaps already lay ground for a future community where the word $r e$ ligion would simply mean that we live our lives in the consciousness of our finitude and thus in an existential and cognitive humility - not far away from what Richard Rorty meant thought when he stated that

My sense of the holy, insofar I have one, is bound with the hope that someday, any millenium now, my remote descendants will live in a global civilization in which love in pretty much the only law. (...) I have no idea how such a society could come about. It is, one might say, a mystery. This mystery, like that of the Incarnation, concerns the coming into existence of a love that is kind, patient, and endures all things. ${ }^{2}$

According to West, »our radical finitude should accent our humble fallibility in science and religion. $\aleph^{3} \mathrm{He}$ also thinks, and I share his view, that we shouldn't see religion in too narrow terms. What is most important, for our dear philosopher and theologian, is the following, and I want to quote from his beautiful talk:

Religious persons like myself must be secularly musical, because, through empathy and imagination, we must try to get inside other peoples' view of the world, to understand why persons are convinced by this set of arguments, thse kinds of reasons as to why they are agnostic or why they're atheistic or what have you. It's no small thing. ${ }^{4}$

This is really very important. We know from broader liberal arts education (and from pragmatism, of course), that the imagination must play a key role in shaping of our intersubjective as well as social and political lives. I also agree with West that too many secular thinkers are religiously tone-deaf and flatfooted, but we must admit that it is also true that among the so called religious persons, there is an equal share of people who are secularly tone-deaf and flatfooted. For both, I think the decisive factor that prevents them to be able to understand the worldviews or preferences of the another camp is precisely a lack of imaginative ability to think beyond their pesonal preferences and worldviews. Martha Nussbaum - in her important book on the future of

2 Rorty, Richard and Vattimo, Gianni, The Future of Religion, Ed. by Santiago Zabala (New York: Columbia University Press 2005), 40.

3 The Power of Religion in the Public Sphere, 95.

4 Ibid., 93 . 
humanities Not For Profit: Why Democracy Needs the Humanities - writes that, simply, cultivation of sympathy with the help of liberal arts should be »a key part of the best modern ideas of democratic education. « ${ }^{5}$ The principal aim of such an education is to »refine the capacity to see the world through another person's eyes. ${ }^{6}$ And to add one more aspect - as a link to my second example in West: in today's so called global world perfection, invulnerability and control (if I borrow Nussbaum's examples here) are highly cherished. But religions teach us for centuries that the world is not so perfect, that we, as human beings, are often much more vulnerable that we are willing to admit, and that we cannot aim to possess the control over any possible aspect of our lives. We need each other more than we would ever be willing to admit: already the current environmental crisis shows us this.

But West's imagination also rests upon another important, perhaps even key topic for us, namely the concept of remembrance. The power of remembrance, as we will see it, lies in its inherent capacity to rethink our modes of citizenship and reorient our political emotions. It must be a key factor of any political theology, in my opinion - at least if we think that plitical theology has something important to do with ethics. West links his thoughts to Judith Butler here. In the same volume, and in an ethico-political sense of a communal cohabitation still to be achieved, Judith Butler reorients our thoughts and sensibilities towards an entirely new concept of citizenship. For Butler, any community (and we shall put religion aside here, since, ultimately, community is a religion, if democracy is realized and fulfilled) is based on a thought that »everyone has the right of belonging. « ${ }^{7}$ According to Butler, following Arendt here,

we may not choose with whom to cohabit but that we must actively preserve the nonchosen character of inclusive and plural cohabitation: we not only live with those we never chose, and to whom we may feel no social sense of belonging, but we are also obligated to preserve those lives and the plurality of which they form a part. In this sense, concrete political norms and ethical prescriptions emerge from the unchosen character of these modes of cohabitation. ${ }^{8}$

'Belonging' is a strong term here and includes an ethically preconditioned form of an inclusive and plural cohabitation in this world. But in order for this futurity of justice to be achieved, another gesture is needed: it is for Butler the

5 Martha C. Nussbaum, Not For Profit: Why Democracy Needs the Humanities (Princeton and Oxford: Princeton UP, 2010), 96.

6 Ibid.

7 Ibid., 85 .

8 Ibid., 84 . 
politico-theological revelation of a Messiah - but not as a concrete person or historical event, but rather as »a memory of suffering from another time that interrupts and reorients the politics of this time. $\ll^{9}$ This temporality of a past and of a future, intertwined and encapsulated in an ethically radicalized shape of a Messiah, is the living memory of past suffering »transposed into the future justice, $«^{10}$ the temporality of justice, and the symbol that I wish that we keep in our minds during this article. For West also, it is simple like that: we may look at the bottom of the Atlantic Ocean and see millions of African bodies there. And the same in nearly every ocean or land. This requires another ethical view, which, for West, was perhaps most poignantly developed by Walter Benjamin, which, of course, is behind both thinkers. In a series of interventions known as The Arcades Project, and in a response to Horkheimer's sadly naïve (žižekian-style) philosophy of history, Walter Benjamin writes following lines, after citing Horkheimer's letter:

On the question of incompleteness of history, Horkheimer's letter of March 16, 1937: »The determination of incompleteness is idealistic if completeness is not comprised within it. Past injustice has occurred and is completed. The slain are really slain.... If one takes the lack of closure entirely seriously, one must belive in the Last Judgement... . Perhaps, with regard to incompleteness, there is a difference between the positive and the negative, so that only the injustice, the horror, the sufferings of the past are irreparable. (...) « The corrective to this line of thinking may be found in the consideration that history is not simply a science but also and not least a form of remembrance $<$ Eingedenken $>$. What science has »determined «, remembrance can modify. Such mindfulness can make the incomplete (happiness) into something complete, and the complete (suffering) into something incomplete. That is theology; but in remembrance we have an experience that forbids us to conceive of history as fundamentally atheological, little as it may be granted us to try to write it with immediately theological concepts. ${ }^{11}$

This contention of Benjamin is in my opinion among the most important interventions in the history of political thought - including political theology, od course - as such. In this theological intervention into the core of historical thinking, Benjamin also ethically disables or disarms historical thinking where

$9 \quad$ Ibid., 83 .

10 Ibid.

11 Walter Benjamin, The Arcades Project, tr. H. Eiland and K. McLaughlin (Cambridge, MA. and London: The Belknap Press of Harvard University Press, 2002), 471. 
violence was able to expiate itself as a work of Love. The politics of violence as a work of love and the question of politics concentrates in my opinion around two blocks, both critical of democracy, but using radically different vocabularies. The first camp of thinkers (Badiou, Žižek and their followers) weaved its new identity around the newly revived idea of communism (followed by an idiosyncratic, as it were, political theology), the second camp aimed at reviving and rescuing the idea and promise of democracy (Mouffe, Ranciére and Derrida). Within the first camp we face the notion of an eternal recurrence of the idea of violence as a necessary historico-eschatological event, being in accordance with the historical intervention into the world of injustices (here Benjamin ressurects in an unfortunate way and in a less theologically sound sense as an initiator of an idiosyncratic and well-known concept of »divine violence of him). »Divine violence« is here identified with historical phenomena of the past: according to Žižek it belongs to the mysterious logic of Event and is related to Love. ${ }^{12}$

But we must return to our first Benjamin: when he claims, that what science has »determined «, remembrance can modify, followed by the observation that such mindfulness can make the incomplete (happiness) into something complete, and the complete (suffering) into something incomplete, he indeed discloses the whole ethical truth of a political theology I want to defend in this essay. Political theology that would be able to be an intervention into the very political core, needs to fulfil a key ethical criterion: I would call this criterion the criterion of a cohabitation, and would tie it to the equally valid ethico-political principles of preserving the lives and lamenting the deaths, as also described earlier in this book. The criterion of cohabitation is fully attuned to what Jean-Luc Nancy portrayed in his The Inoperative Community with the following words:

Millions of deaths, of course, are justified by the revolt of those who die: they are justified as a rejoinder to the intolerable, as insurrections against social, political, technical, military, religious oppresion. But these deaths are not sublated: no dialectic, no salvation leads these deaths to any other immanence than that of ... death ...13

12 See Slavoj Žižek, Violence (London: Profile Books, 2008), especially when he is dealing with Che Guevara and Kierkegaard. For Benjamin and »divine violence« see his essay »Critique of violence«, in On Violence: A reader, eds. Bruce B. Lawrence and Aisha Karim (Durham: Duke University Press, 2007), 268-285.

13 Jean-Luc Nancy, The Inoperative Community, ed. Peter Connor (Minneapolis: University of Minnesota Press, 1991), 13. On this see my Pragmatist Variatons on Ethical and Intercultural Life (Lanham / Boulder / New York / Toronto / Plymouth, UK: Lexington Books, 2013), ch. 8. 
Now, this tension within the very concept of insurrection is what is the most interesting part of a contemporary political theology. In An Insurrectionist Manifesto, Jeffrey Robbins is guiding us on this path in his insightful essay »A Theory of Insurrection: Beyond the Way of the Mortals«. Robbins begins his insurrectionist theological meditation by questioning the American legacy of lynching (1880-1940) in which there were nearly five thousand African American victims. ${ }^{14}$ According to Robbins' hero, a black liberation theologian James Cone (who, of course, is one of the key predecessors of West), any theology worth of its name should address convincingly the religious struggle for justice as related to the victims of history, not historically starting, but still theologally being initiated with the crucifixion of Jesus Christ. According to Robbins,

Jesus' death was not an isolated incident. On the contrary, what both the cross and the lynching tree reveal is not a single, exclusive point in human history wherein an innocent victim was made to die, but that this is a terrible truth that societies repeat, almost ineluctably. ${ }^{15}$

Here lies the difference between two concepts - namely, resurrection and insurrection, as defended by Robbins and his theological bystanders. This difference, in my opinon, mirrors the dichotomy between two opposing camps in contemporary political philosophy - between those who do believe that violence can somehow expiate itself miraculously in the course of the world history and its inherent (or theologically 'postponed') eschatology, and those that oppose such a gesture and do not relate history to the recurrent Event of Love (being not yet realized, or even failed (»Try again, Fail again. Fail better«), but still preserved and kept in our political memories as a variant of a regulative idea) or any other expiatory gesture. It is also a dichotomy that marks Johann Baptist Metz's theology, known as Memoria Passionis, where Metz insists, that theodicy in its (perverse) care for the perpetrators should be dethroned from the theology's pedestal and replaced with the struggle for justice from the point of the view of the innocent victims. For Metz, in his essay »In the Pluralism of Religious and Cultural Worlds«, it is the authority of sufferers that should guide our »communities of memory«, as Metz calls our societies, and, in view of living in a world of udeniable plurality, he defends a kind of an universalist approach by proposing the following credo:

\footnotetext{
14 Ward Blanton, Clayton Crockett, Jeffrey W. Robbins and Noëlle Vahanian, An Insurrectionist Maniffesto: Four New Gospels for a Radical Politics (New York: Columbia University Press, 2016), 111. 
Isn't it resistance to unjust suffering, largely inspired by respect for the authority of those who suffer, which brings humankind together from quite diverse religious and cultural worlds? (...) Here I see the opportunity and task for an ecumenism of religions that takes the form of an indirect ecumenism of religions - in accord with the thinking of the new political theology. ${ }^{16}$

This should be the common ground of all post-religious communities as I understand them. It is the memory of suffering that should guide our thoughts and awaken our compassions. And it is precisely this memoria passionis that should guide any politico-ethical or theologico-eschatological visions that we may have. But there is a question I wish to address in the concluding section of this article. Namely, is there a method or concept in philosophy of religion that would be able to to support such an ecumenic thinking? I am thinking of a West introductory remark on secularists being tone deaf, or my remark on religious persons being tone deaf as well. In my opinion, there is no better method than the Deweyan pragmatist attempt in his A Common Faith.

\section{The second temporality of religion: from Dewey to Unger}

We now need to look into our second temporality - if remembrance was guiding our quest to understand the past, then imagination must guide our endeavour to understand the future. Douglas R. Anderson points to a continuity in the philosophical thought of Edwards, Thoreau and Dewey. They all position »God « within the finiteness of our experience: stress is laid on the human faculty of imagination, either religious or other, which opens up the horizons of the infinite or the ideal. The key criterion of succesful inquiry is the ability to make a difference to practice or, more broadly speaking, to experience and to life. Dewey was an ardent advocate of the middle path between aggressive atheism on the one hand and faith in the supernatural on the other - and perhaps this is also where he was most misunderstood. God, for Dewey, is a growing tradition, and the new meaning of God is being revealed through the human imaginative faculty - precisely the one that we have recognized as a key factor previously. Imagination is treated by Dewey as the entry of asyet-unachieved things into the horizons of our existence and I want to add this view to the more theologically underspinned memoria passionis style of thinking. If the first temporality was related to the memory and remembrance, the

16 Love's Strategy: The Political Theology of Johann Baptist Metz, ed. by John K. Downey (Harrisburg: Trinity Press, 1999), 172. 
second temporality is linked to shaping and preserving in a way our shared future hopes. It is now through the process of approaching the ideal purpose and end of action(s), of nearing the imaginative idea and the limit point, that the projection of an entirety in terms of the pragmatist ideal is visible. Here Dewey inverts the traditional line of thought: each new adaptation, each change in life, especially one concerning »our being in its entirety, «17 is religious in character. He adds, not without theological implications, that this is not some individual change in will, but a thoroughgoing and organic change of will - i.e., to put it in theological jargon, grace. ${ }^{18}$ Everything unknown, future, invisible - this, in its potentiality, is the object of our faith, positioned within an historical and social framework: »Faith in the continued disclosing of truth through directed cooperative human endeavor is more religious in quality than is any faith in a completed revelation. $«^{19} \mathrm{But}$ in this, on this path, a specific, culturally conditioned religious belief may of course be of great benefit to an individual. Dewey defines the religious character of human striving for fulfillment as follows:

Any activity pursued in behalf of an ideal end against obstacles and in spite of threats of personal loss because of conviction of its general and enduring value is religious in quality. Many a person, inquirer, artist, philanthropist, citizen, men and women in the humblest walks of life, have achieved, without presumption and without display, such unification of themselves and of their relations to the conditions of existence. It remains to extend their spirit and inspiration to ever wider numbers. ${ }^{20}$

For Dewey, the idea of God is that of unity of all the ideal purposes determining our actions. In this context, ideals are to be comprehended as faith in the unknown, as the mathematical limit upheld by »the hard stuff of the world of physical and social experience, $\ll^{21}$ and not as truth conceived of as the Platonist end that has all along been known though not yet grasped. In the historical process of humanity's life, ideals are subject to constant testings of their use and improvement value. Dewey might have believed that people internally and ideally tend towards justice and compassion as he was developing the idea of democracy. But he condemns all the metaphysical and theological tenets concerning the supernatural with as much vigor as he does aggressive atheism

\footnotetext{
17 John Dewey, A Common Faith, (New Haven and London: Yale UP, 1971), 16.

18 Dewey himself points out that such change of will is not voluntary.

19 Dewey, op. cit., 26.

$20 \quad$ Op. cit., 27.

21 Op. cit., 49.
} 
and modern agnosticism. For Dewey, the idea of God, therefore must be linked to the idea of the divine. Dewey writes about it:

This idea is, as I have said, one of ideal possibilities unified through imaginative realization and projection. But this idea of God, or of the divine, is also connected with all the natural forces and conditions - including man and human association - that promote the growth of the ideal and that further its realization. (...) It is this active relation between ideal and actual to which I would give the name »God.«22

Dewey's idea of God (of the divine) is important for our genealogy precisely as a method of philosophy of religion, which is having a weak theological call on one, and a strong socio-ethical potential on the other hand. Roberto Mangabeira Unger, finally, is able to express this call in his excellent The Religion of the Future. ${ }^{23}$ Unger is among the most original thinkers both within and beyond pragmatist philosophy of religion. I wish to dedicate my attention to one of the virtues, that comes closest to our initial constellation, namely the vitrue of an enhanced vulnerability. But before that, let us look into the genealogy of the, as it were, ethical dynamics in religon. According to Unger, in his The Religion of the Future,

All the religions of transcendence, each in its own way, insisted on replacing the ethic of martial valor, of pride and self-assertion, dear to the fighting and ruling classes of the past, with an ethic of inclusive solidarity and fellow feeling. This substitution found support in the denial of the reality of authority of all divisions within mankind. Such was the truth proclaimed in Buddhism and Confucianism as well as in Judaism, Christianity, and Islam. ${ }^{24}$

Now, philosophers of religion and others have made one more step which we could understand as a step into what we today undestand as political theology: Also according to Unger, now put in a slightly more 'Eurocentric' (or Westernized) way, we now have the following constellation:

It was the distinctive achievement of the struggle with the world, in all its theistic and secular forms, especially in Christianity, democracy, and romanticism, to have subordinated this ethical universalism to another

\footnotetext{
22 Ibid., 5 of.

23 R.M. Unger, The Religion of the Future (Cambridge, Mass.: Harvard University Press, 2014).

24 Ibid., $35^{2}$.
} 
moral vision: one in which our ability to imagine and accept one another (in love, and in higher forms of cooperation) and our capacity to see and act beyond the limits of the established structures of life and thought become the commanding impulses. (...) The crucial element in the turn taken by the struggle with the world is the marriage of our ideas about connection and cooperation with our ideas about the longing for the infinite. $^{25}$

The virtue of enhanced or heightened vulnerability is the culmination of the above mentioned process and it links both temporalities that were mentioned. It is the requirement for other virtues, which guide our quest for greater love and higher forms of cooperation. This quest is the common task of all humanity, regardless of any particular form of religion or religious ethic. Finally, among the three sets of virtues (of connection, of purification and of divinization) the latter are of the highest importance: virtues of divinization, for Unger, are faith, hope, and charity. Hope is the openness to the new, charity is the openness to the other, and vulnerability is linked to faith. This acceptance of risk and vulnerability in ourselves or in our lives helps us to become patient and to move toward life-giving contexts rather than away from them (like moving toweards nihilistic vitrues such as fear, anger, and ultimately, violence). Vulnerability as, (i) our capacity to be wounded, (ii) the contingency of the world, (iii) the fragility of our existence, and (iv) our human fallibility, ${ }^{26}$ teaches us to imagine our lives, and lives of other people through ethical lenses. We know that we all are much more fragile as we could ever admit. Our religions help us shaping our hopes, and our faith guides us in becomiong more godlike through charity as an enhanced and compassionate awareness of the needs of other people, and even other cratures.

\section{Conclusion}

Based on this genealogy of both remembrance and vulnerability, the aim of us, pragmatist political theologians should be to first look at religion in its radicalized ethico-political form (expressed in both priority of memoria passionis and remembrance as well as its imaginative projective force as community or even democracy realized) which only later enables us to think about its various variations and incarnations within different traditions and cultures. This of course

\footnotetext{
25 Ibid.

26 See Clemens Sedmak, »Peace, Vulnerability, and Human Imagination«, in: Poesis of Peace, ed. by K.-G. Giesen, C. Kersten and L. Škof (London and New York: Routledge 2017), 32.
} 
is a philosophical argument for a political theology. It still is a mystery, similar to what Rorty also thought, how this could happen. But I would argue that it is within this newly acquired double temporality of religion that it is possible to imagine a future place where recurrent hope for $a$ life is reborn and nurtured within future pluralistic / inclusivistic / democratic / post-Christian (and, by analogy, post-Islamic, post-Hindu, post-Confucian etc.) communities, based on compassion and shared vulnerability, and not any more on power, or any other form of violence.

\section{Acknowledgement}

This article was published with the financial support of Slovenian Research Agency grants J6-9353 and J6-8265.

\section{Works Cited}

Benjamin, Walter. The Arcades Project. Tr. H. Eiland and K. McLaughlin. Cambridge, MA. and London: The Belknap Press of Harvard University Press, 2002.

Blanton, Ward, Crockett, Clayton, Robbins, Jeffrey W. and Vahanian, Noëlle. An Insurrectionist Maniffesto: Four New Gospels for a Radical Politics. New York: Columbia University Press, 2016.

Dewey, John. A Common Faith. New Haven and London: Yale UP, 1971.

Downey, John K., ed., Love's Strategy: The Political Theology of Johann Baptist Metz. Harrisburg: Trinity Press, 1999.

Lawrence, Bruce B. and Karim, Aisha, eds. On Violence: A reader. Durham: Duke University Press, 2007.

Mendieta, E. and Vanantwerpen, J. The Power of Religion in the Public Sphere. New York: Columbia University Press, 2011.

Nussbaum, Martha C. Not For Profit: Why Democracy Needs the Humanities. Princeton and Oxford: Princeton UP, 2010.

Nancy, Jean-Luc. The Inoperative Community. Ed. by Peter Connor. Minneapolis: University of Minnesota Press, 1991.

Rorty, Richard and Vattimo, Gianni. The Future of Religion. Ed. by Santiago Zabala. New York: Columbia University Press 2005.

Sedmak, Clemens. »Peace, Vulnerability, and Human Imagination «. In: Poesis of Peace, ed. by K.-G. Giesen, C. Kersten and L. Škof. London and New York: Routledge 2017.

Unger, R.M. The Religion of the Future. Cambridge, Mass.: Harvard University Press, 2014.

Žižek, Slavoj. Violence. London: Profile Books, 2008. 